\section{₹USGS}

science for a changing world

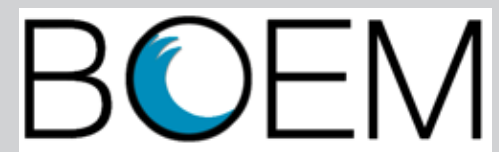

Bureau of Ocean Energy Management

Prepared in cooperation with the Bureau of Ocean Energy Management

\title{
Bathymetry and Acoustic Backscatter-Outer Mainland Shelf, Eastern Santa Barbara Channel, California
}

By Peter Dartnell, David P. Finlayson, Andrew C. Ritchie, Guy R. Cochrane, and Mercedes D. Erdey

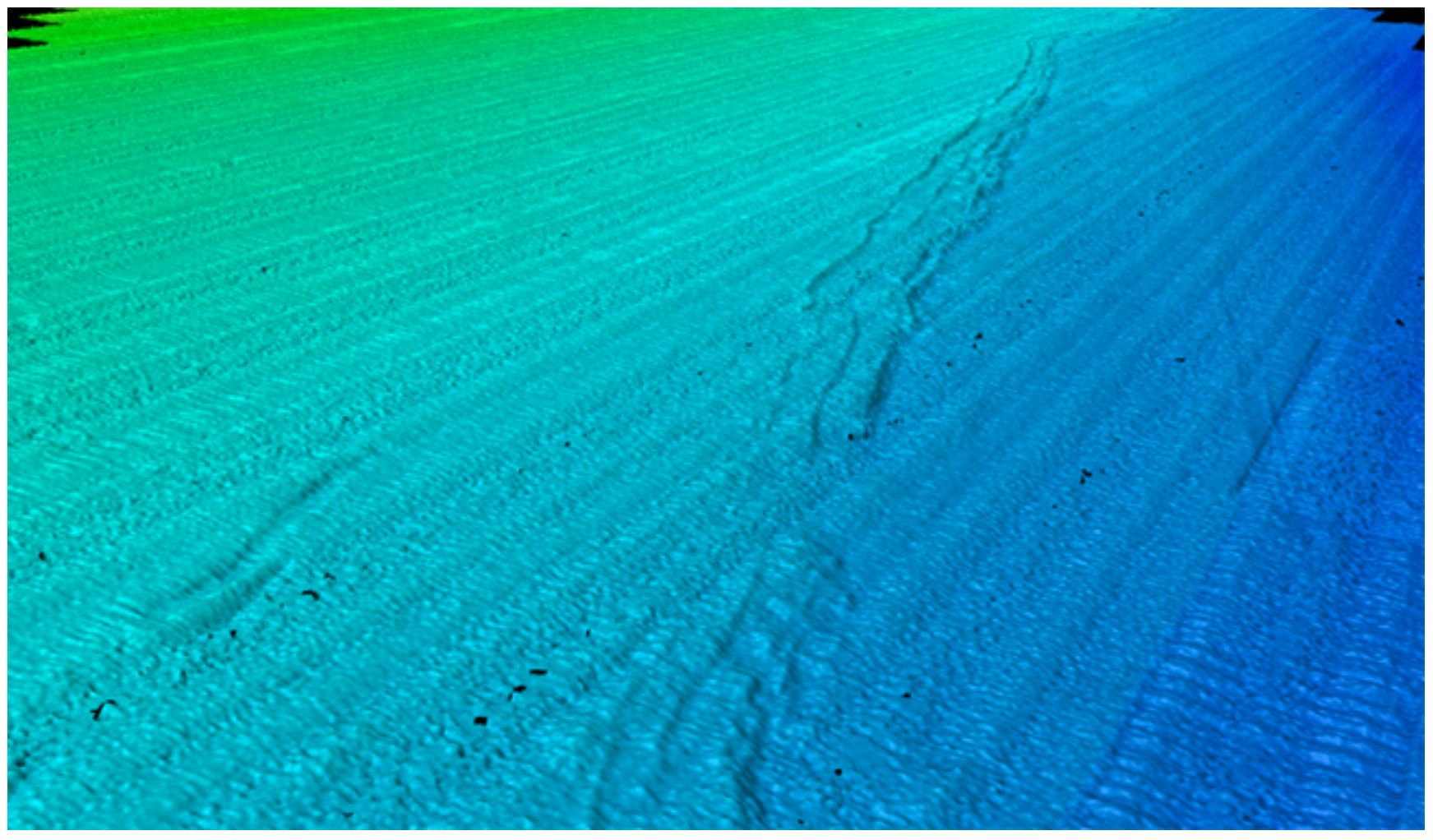

Data Series 702

Bureau of Ocean Energy Management OCS Study BEOM 2012-029

U.S. Department of the Interior

U.S. Geological Survey 


\section{U.S. Department of the Interior \\ KEN SALAZAR, Secretary}

\section{U.S. Geological Survey \\ Marcia K. McNutt, Director}

U.S. Geological Survey, Reston, Virginia 2012

For product and ordering information:

World Wide Web: http://www.usgs.gov/pubprod

Telephone: 1-888-ASK-USGS

For more information on the USGS - the Federal source for science about the Earth, its natural and living resources, natural hazards, and the environment:

World Wide Web: http://www.usgs.gov

Telephone: 1-888-ASK-USGS

Cover illustration:

Perspective view of colored shaded relief bathymetry southeast of Santa Barbara.

Suggested citation:

Dartnell, P., Finlayson, D.P., Ritchie, A.C., Cochrane, G.R., and Erdey, M.D., 2012, Bathymetry and Acoustic Backscatter-Outer Mainland Shelf, Eastern Santa Barbara Channel, California: U.S. Geological Survey Data Series 702 [http://pubs.usgs.gov/ds/702/].

Any use of trade, product, or firm names is for descriptive purposes only and does not imply endorsement by the U.S. Government.

Although this report is in the public domain, permission must be secured from the individual copyright owners to reproduce any copyrighted material contained within this report. 


\section{Contents}

Conversion Factors ……….........................................................................................................

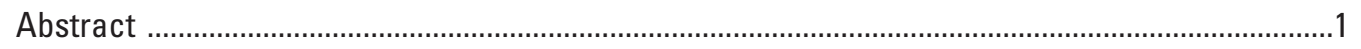

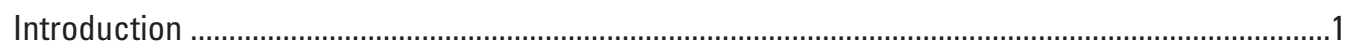

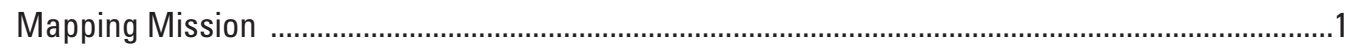

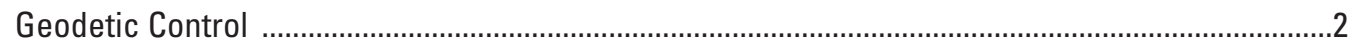

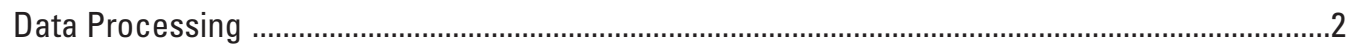

Vessel Position and Attitude .................................................................................................. 2

Sound Velocity Measurements ............................................................................................

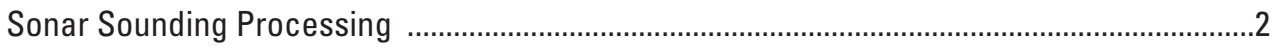

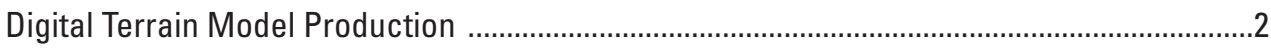

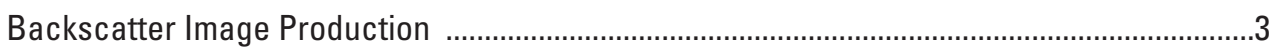

Estimates of Bathymetric Uncertainty ...............................................................................

Merged bathymetry of the Santa Barbara Channel ....................................................................

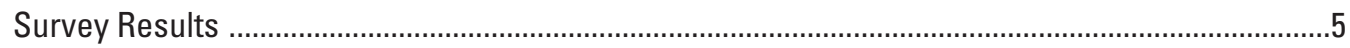

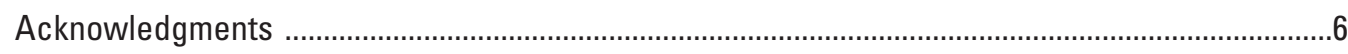

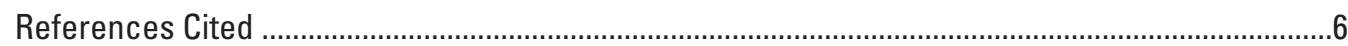

\section{Figures}

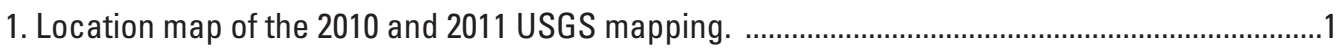

2. Photograph of the U.S. Geological Survey R/V Parke Snavely. ................................................

3. Plan view of shaded-relief bathymetry of the eastern Santa Barbara Channel. ...........................

4. Normalized backscatter amplitude of the eastern Santa Barbara Channel. ..................................

5. Colored shaded-relief bathymetry map of the Santa Barbara Channel generated by merging available swath bathymetry data including the new 2010-2011 USGS data. ........................5

\section{Tables}

1. SWATHplus-M Sonar Specification (System Engineering and Assessment (Advanced Products) Ltd., 2004). ........................................................................................................

2. GPS base station coordinates used for the 2010-2011 USGS survey in the eastern Santa

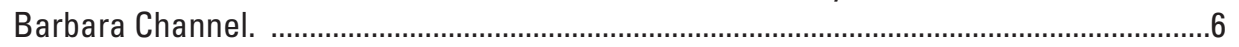




\section{Conversion Factors}

Inch/Pound to SI

\begin{tabular}{lcl}
\hline \multicolumn{1}{c}{ Multiply } & By & \multicolumn{1}{c}{ To obtain } \\
\hline inch (in.) & Length & \\
inch (in.) & 2.54 & centimeter $(\mathrm{cm})$ \\
foot (ft) & 25.4 & millimeter $(\mathrm{mm})$ \\
mile (mi) & 0.3048 & meter $(\mathrm{m})$ \\
mile, nautical (nmi) & 1.609 & kilometer $(\mathrm{km})$ \\
yard (yd) & 1.852 & kilometer $(\mathrm{km})$ \\
\hline & 0.9144 & meter $(\mathrm{m})$ \\
\hline acre & Area & \\
acre & 4,047 & square meter $\left(\mathrm{m}^{2}\right)$ \\
acre & 0.4047 & hectare $(\mathrm{ha})$ \\
acre & 0.4047 & square hectometer $\left(\mathrm{hm}^{2}\right)$ \\
square foot $\left(\mathrm{ft}^{2}\right)$ & 0.004047 & square kilometer $\left(\mathrm{km}^{2}\right)$ \\
square inch (in $\left.{ }^{2}\right)$ & 929.0 & square centimeter $\left(\mathrm{cm}^{2}\right)$ \\
square foot $\left(\mathrm{ft}^{2}\right)$ & 0.09290 & square meter $\left(\mathrm{m}^{2}\right)$ \\
section $\left(640 \mathrm{acres}^{2}\right.$ or 1 square mile) & 259.0 & square hectometer $\left(\mathrm{hm}^{2}\right)$ \\
square mile $\left(\mathrm{mi}^{2}\right)$ & 259.0 & hectare $($ ha) \\
square mile $\left(\mathrm{mi}^{2}\right)$ & 2.590 & square kilometer $\left(\mathrm{km}^{2}\right)$ \\
\hline
\end{tabular}




\section{Abstract}

In 2010 and 2011, scientists from the U.S. Geological Survey (USGS), Pacific Coastal and Marine Science Center (PCMSC), acquired bathymetry and acoustic-backscatter data from the outer shelf region of the eastern Santa Barbara Channel, California. These surveys were conducted in cooperation with the Bureau of Ocean Energy Management (BOEM). BOEM is interested in maps of hard-bottom substrates, particularly natural outcrops that support reef communities in areas near oil and gas extraction activity. The surveys were conducted using the USGS R/V Parke Snavely outfitted with an interferometric sidescan sonar for swath mapping and realtime kinematic navigation equipment. This report provides the bathymetry and backscatter data acquired during these surveys in several formats, a summary of the mapping mission, maps of bathymetry and backscatter, and Federal Geographic Data Committee (FGDC) metadata.

\section{Introduction}

The U.S. Geological Survey (USGS), Pacific Coastal and Marine Science Center (PCMSC), in cooperation with the Bureau of Ocean Energy Management (BOEM), completed mapping of the outer shelf region of the eastern Santa Barbara Channel, southern California. High-resolution bathymetry and co-registered acoustic backscatter data were collected from south of Santa Barbara to west of Oxnard, mainly seaward of the 3-nautical-mile limit of California's State Waters (fig. 1).

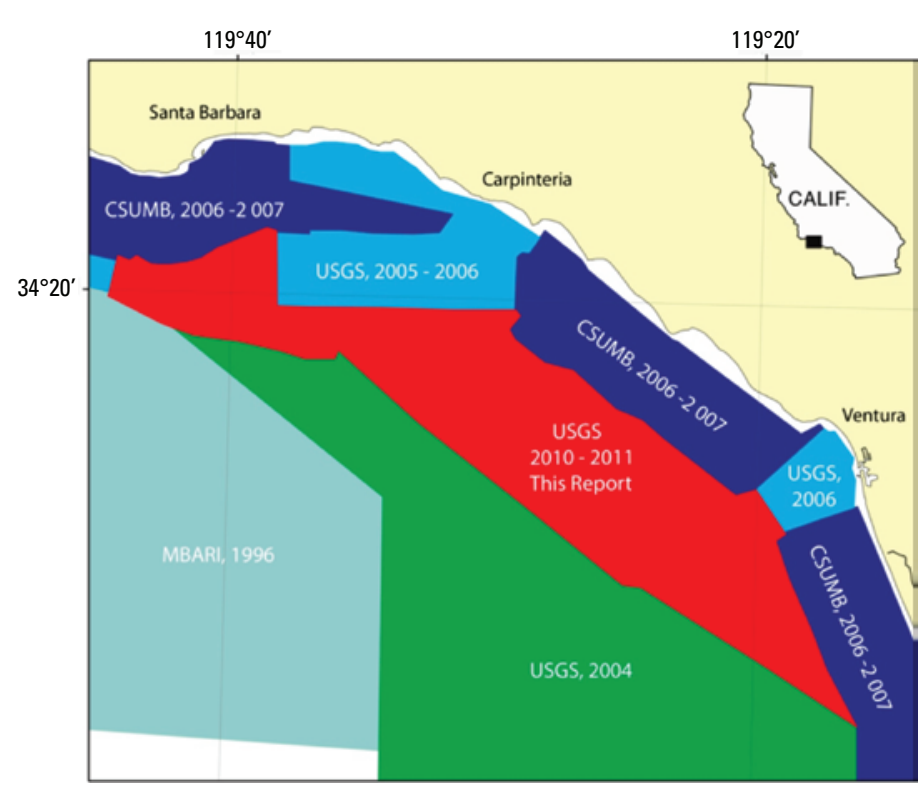

Figure 1. Location map of the 2010 and 2011 USGS mapping (colored red). Other colored polygons show previously mapped regions of the Santa Barbara Channel, including institution and year. CSUMB, California State University, Monterey Bay; MBARI, Monterey Bay Aquarium Research Institute; USGS, U.S. Geological Survey.
This was the last remaining area to be mapped in the Santa Barbara Channel with high-resolution mapping tools, except for regions around the northern Channel Islands. The USGS surveys abutted data previously collected within California State Waters by California State University, Monterey Bay, Seafloor Mapping Lab; Fugro Pelagos, Inc.; and the USGS and further offshore by the Monterey Bay Aquarium Research Institute (MBARI) and the USGS (fig. 1). While most of the newly mapped region consisted of low-relief, lower-backscatter seafloor, local regions of higher relief with higher backscatter intensities were mapped in the northern extent of the survey area. Pipelines and (or) cables were mapped throughout the region. A field of scattered mounds of higher backscatter intensities was mapped in the southern extent of the survey area.

These new data can be used to help researchers, coastalzone managers, and other stakeholders better understand the coastal environment including identifying hard-bottom substrates, such as natural outcrops that support reef communities; prediction of sediment and contaminant budgets and transport; and assessment of earthquake and tsunami hazards in the region. This report provides the USGS 2010 and 2011 bathymetry and backscatter data in several formats along with a summary of the mapping mission, maps of bathymetry and backscatter, and Federal Geographic Data Committee (FGDC) metadata. This report also provides a new overall $10-\mathrm{m}$ resolution bathymetric Digital Terrain Model (DTM) of the Santa Barbara Channel incorporating these new bathymetry data with other available bathymetric data.

\section{Mapping Mission}

Due to the overall size of the mapping area within shallower waters, the mapping took place over a two-year period between 2010 and 2011 (PCMSC Field Activity IDs: S-14-10-SC and S-08-11-SC). Both surveys were conducted using a $234.5 \mathrm{kHz}$ SEA (Systems Engineering and Assessment (Advanced Products) Ltd.) SWATHplus-M phase-differencing sidescan sonar. The sonar was mounted on the 34-ft USGS mapping vessel R/V Parke Snavely (fig. 2) and affixed to a

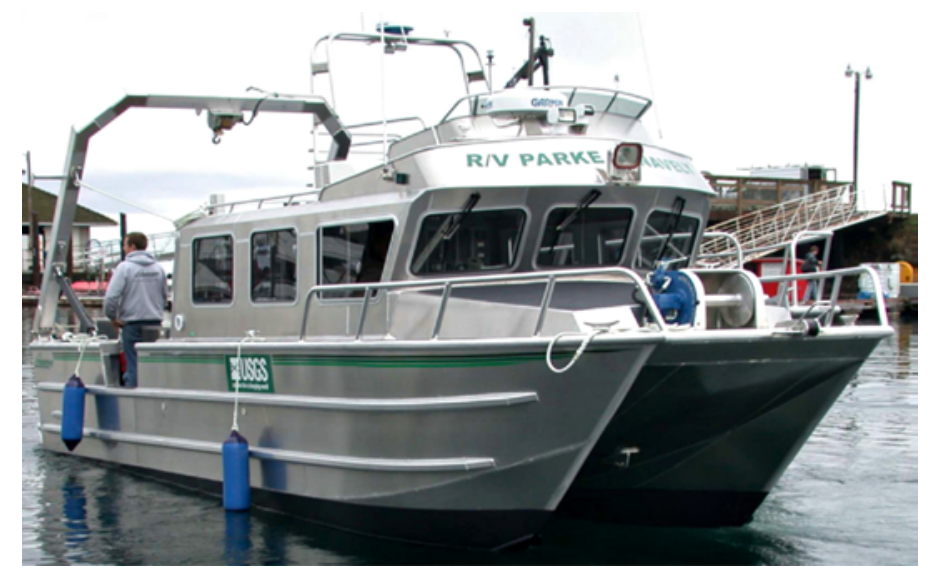

Figure 2. Photograph of the U.S. Geological Survey R/V Parke Snavely. 
hull brace. Real-time kinematic (RTK) GPS position data were passed through a CodaOctopus F190 inertial measurement unit (IMU) to the sonar hardware and data collection software. The R/V Parke Snavely was outfitted with three networked workstations and a navigation computer for use by the captain and survey crew for data collection and initial processing. See table 1 for the sonar system specifications.

The surveys were completed over 24 days in 2010, from June 28 to July 21, and over 20 days in 2011, from July 6 to July 26. In 2010, over $104 \mathrm{~km}^{2}\left(40 \mathrm{mi}^{2}\right)$ of seafloor were mapped in water depths ranging from 15 to $105 \mathrm{~m}$. In 2011, over $95 \mathrm{~km}^{2}\left(36 \mathrm{mi}^{2}\right)$ of seafloor were mapped in water depths ranging from 20 to $74 \mathrm{~m}$.

\section{Geodetic Control}

Geodetic control for the surveys were established using shore-based Global Positioning System (GPS) base stations broadcasting real-time kinematic (RTK) corrections to the survey vessel by UHF radio link. For the northwestern extent of the mapping area, an existing base station was used atop a tall building on the University of California, Santa Barbara, campus. For the central and southeastern extents of the survey area a station was established atop a tall building on the coast in Ventura. The base stations were programmed using the World Geodetic System of 1984 (WGS84) (G1150) reference frame with an Epoch date of 6/30/2010 (2010.49589041096). Average National Geodetic Survey Opus Solution coordinates for the Ventura station are shown in table 2.

\section{Data Processing}

\section{Vessel Position and Attitude}

The R/V Parke Snavely was equipped with a CodaOctopus F190 inertial motion unit (IMU) for the duration of both the surveys. The F190 received real-time kinematic (RTK) corrections directly from the base stations. The RTK GPS data $(2-\mathrm{cm}$ error ellipse) are combined with the inertial motion measurements directly within the F190 hardware so that high-precision position and attitude corrections were fed in real time to the sonar acquisition equipment. The WGS84 (G1150) Epoch 2010.49589041096 3-dimensional reference frame was used for all data acquisition.

\section{Sound Velocity Measurements}

Sound velocity measurements were collected continuously with an Applied Micro Systems Micro Sound Velocimeter deployed on the transducer frame for real-time sound velocity adjustments at the transducer-water interface. The Micro SV is accurate to $\pm 0.03 \mathrm{~m} / \mathrm{s}$. In addition, sound velocity profiles (SVP) were collected approximately every 2 hours throughout each survey day with an Applied Micro Systems SvPlus 3472.
This instrument provided time-of-flight sound-velocity measurements by using invar rods with a sound-velocity accuracy of $\pm 0.06 \mathrm{~m} / \mathrm{s}$. Pressure measured by a semiconductor bridge strain gauge to an accuracy of 0.15 percent ( $500 \mathrm{dbar}$, full scale) and temperature was measured by thermistor with an accuracy of 0.05 degrees Celsius (Applied Microsystems Ltd., 2005).

\section{Sonar Sounding Processing}

GPS data and measurements of vessel motion were combined in the F190 hardware to produce a high-precision vessel attitude packet. This packet was transmitted to the Swath Processor acquisition software in real time and combined with instantaneous sound velocity measurements at the transducer head before each ping. As many as 20 pings per second were transmitted with each ping consisting of 2,048 samples per side (port and starboard). The returned samples were projected to the seafloor using a ray-tracing algorithm working with the previously measured sound-velocity profiles in SEA Swath Processor (version 3.07.12.0). A series of statistical filters were applied to the raw samples that isolated the seafloor returns from other spurious targets in the water column. Finally, the processed data were stored line-by-line in both raw (.sxr) and processed (.sxp) trackline files.

\section{Digital Terrain Model Production}

CARIS HIPS and SIPS (version 7.1.1 Service Pack 3) bathymetry processing software was used to further clean and bin the raw bathymetry. Processed .sxp files were imported to CARIS and seven field sheets (Blocks A-G) were created within CARIS to encompass the entire survey area.

Survey lines were filtered to remove obvious erroneous soundings and soundings towards the noisier out beams and then gridded into the appropriate field sheet. CARIS base surfaces were created for each field sheet at 2-m resolution. The base surfaces were then exported as ASCII XYZ files (x coordinate, y coordinate, depth).

The XYZ triplicate files were transformed from the WGS84 (G1150) ellipsoid to the North American Datum of 1983 (NAD83) CORS96 ellipsoid using a 14-point Helmert transformation using the parameterization described in Soler and Snay (2004) with the command line tool CS2CS in the Proj4 library (http://trac.osgeo.org/proj/). The parameters were calculated for an Epoch date of 2010. The NAD83 XYZ data were gridded in Fledermaus (QPS) software (Version 7.1) at 2-m resolution and the resulting surfaces were converted to ASCIIRaster format files and imported into a GIS (ESRI, ArcMap).

Following the NOAA National Geodetic Survey (2009) GEOID09 website, http://www.ngs.noaa.gov/GEOID/ GEOID09/, there is a $36.275-\mathrm{m}$ vertical offset between the NAD83 ellipsoid heights and NAVD88 altitudes in the northwestern section of the survey area and a vertical offset of $36.388 \mathrm{~m}$ in the southeastern section of the survey area. Therefore a static offset of $36.331 \mathrm{~m}$ was applied to the bathymetric surface models to convert the NAD83 (CORS96) ellipsoid 
elevations into NAVD88 altitudes. These processed bathymetry data (Blocks A-G) (fig. 3) are available in the online Data Catalog section of this report (http://pubs.usgs.gov/ds/702/) as ASCIIRaster (.asc) and geoTIFF (shaded relief bathymetry) format files.

\section{Estimates of Bathymetric Uncertainty}

Although the USGS collects bathymetry and acoustic backscatter data for research purposes only (not for navigation charts) it is important to access the accuracy of the data.

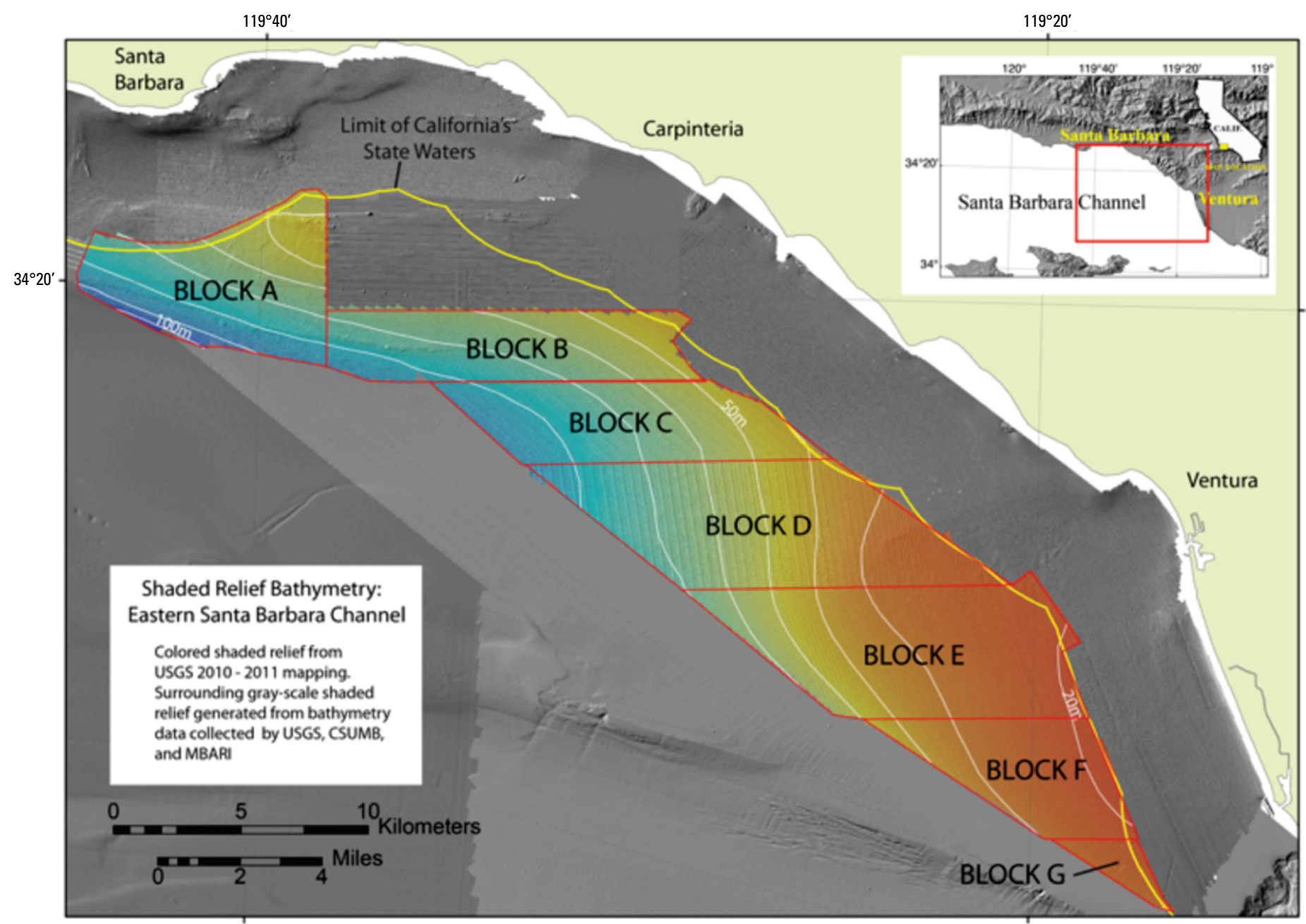

Figure 3. Plan view of shaded-relief bathymetry of the eastern Santa Barbara Channel. The 2010 and 2011 USGS mapped area is colored for depth: reds (shallower) to blues (deeper). The surrounding gray shaded-relief bathymetry is generated from bathymetry data collected by California State University, Monterey Bay Seafloor Mapping Lab (CSUMB); the Monterey Bay Aquarium Research Institute (MBARI); and the USGS. Red outlines show the location of the individual bathymetry files (Blocks $A-G$ ) available in the Data Catalog section of this report.

\section{Backscatter Image Production}

The raw 16-bit backscatter data recorded simultaneously with bathymetry by the SWATHplus was georeferenced and gain-normalized by the program SXPEGN software written by the USGS to enhance the backscatter of the SWATHplus system. The program normalizes for time-varying signal loss and beam directivity differences. The resulting normalized amplitude values are re-scaled to 16 bit, and gridded into GeoJPEGS using GRID Processor Software supplied by SEA. The images (Blocks A-G) were converted to geoTIFF images using ESRI GIS software (fig. 4). These geoTIFFs are available in the online Data Catalog section of this report (http://pubs.usgs.gov/ ds/702/).
Finlayson and Warrick (written commun., 2012) demonstrate that the standard deviation of soundings in areas of lower relief is a good measure of the precision of the sonar measurements. These absolute numbers are a good indication of the distribution of uncertainty in bathymetric soundings, however bathymetric errors naturally increase with range from the system (depth). By comparing calculated Total Vertical Uncertainty (TVU) with standardized IHO TVU survey order thresholds, which are based on a combination of coverage, depth, and accuracy (International Hydrographic Organization, 2008), we can access the accuracy of the bathymetry data in this report. Finlayson and Warrick (in review), define TVU as

$$
\operatorname{TVU}_{(\mathrm{x}, \mathrm{y})}=1.96 \times \sigma_{(\mathrm{x}, \mathrm{y})} \text {. }
$$

where $\sigma_{(x, y)}$ is the standard deviation of a cell located at coordi- 


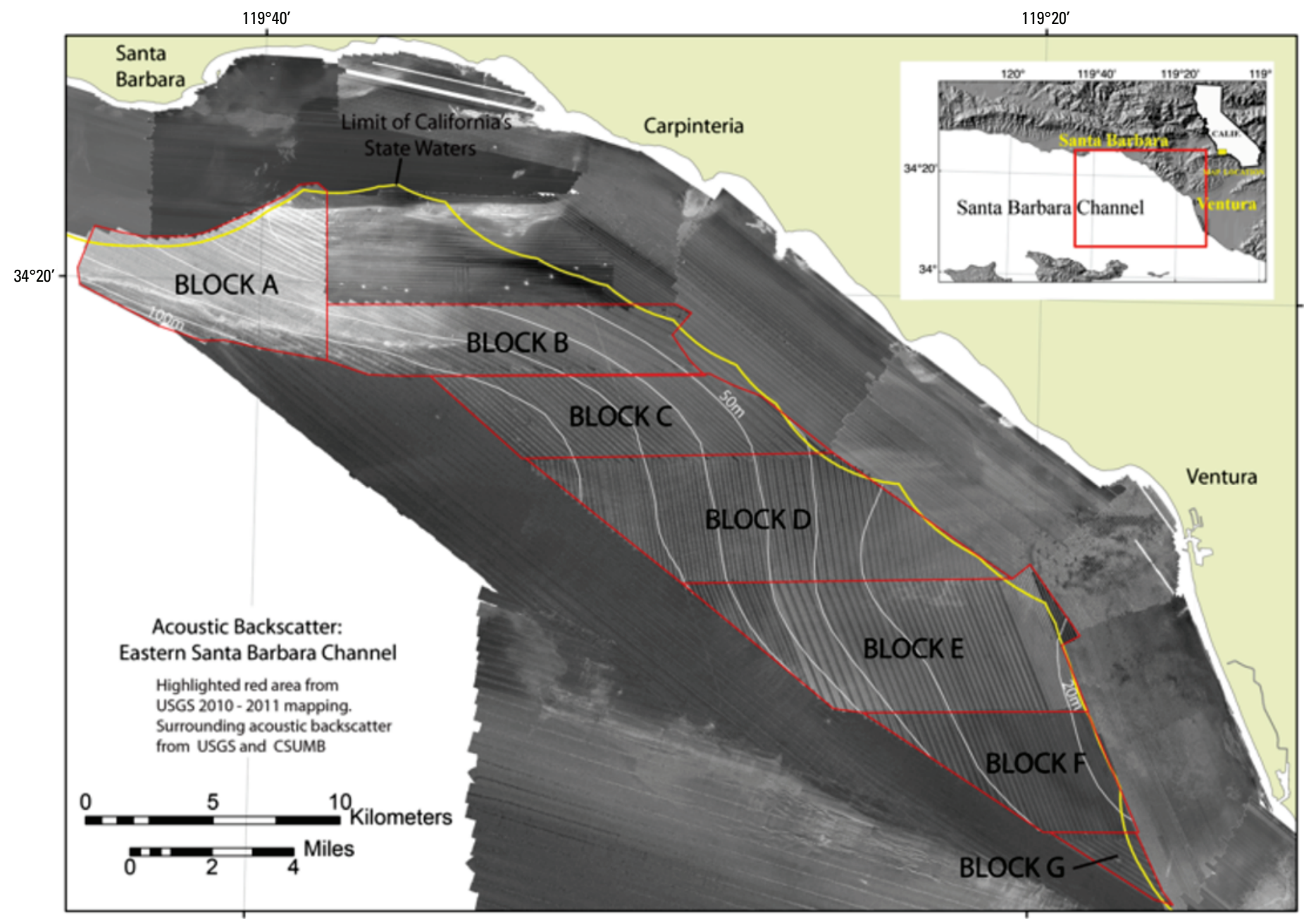

Figure 4. Normalized backscatter amplitude of the eastern Santa Barbara Channel. Red outlines show the location of the individual backscatter files (Blocks A-G) available in the Data Catalog section of this report. The surrounding backscatter imagery is from California State University, Monterey Bay Seafloor Mapping Lab (CSUMB) and USGS.

nate $(\mathrm{x}, \mathrm{y})$. Standard deviation values for each of the Caris field sheets (Blocks A-G) were exported as ASCII XYZ files. These files were gridded in Fledermaus and converted to ESRI GRIDs. TVU was calculated using GIS raster math with equation 1.

\section{Merged bathymetry of the Santa Barbara Channel}

Higher resolution mapping within the channel has occurred over the past 13 years by various institutions including Monterey Bay Aquarium Research Institute, USGS, California State University, Monterey Bay, Seafloor Mapping Lab, and Fugro Pelagos, Inc. This report has compiled all of the bathymetry data and merged the datasets into one overall 10-m-resolution Digital Terrain Model (DTM). NOAA previously generated a 10-m-resolution Tsunami Inundation DTM of the entire channel that merged the available bathymetry data with onshore topography data (Carignan and others, 2009). This report provides an updated bathymetric DTM that includes more recent bathymetry data including the 2010-2011 USGS bathymetry data. No attempt was made here to merge the new bathymetric DTM with onshore topography.

MBARI bathymetry data from their 1998 survey of the deeper central and western channel are available in MBSystems format files from the National Geophysical Data Center (NGDC) bathymetry data server, http://maps.ngdc.noaa.gov/ viewers/bathymetry/. XYZ soundings (x coordinate, y coordinate, depth) were extracted from the survey lines, gridded into a 10-m resolution bathymetric surface using the Fledermaus (QPS) software package, and imported into a GIS (ESRI, ArcMap). USGS bathymetry data from the 2004 survey of the deeper eastern channel are also available from the NGDC bathymetry data server. This project however, used the raw survey lines from the USGS archives. Survey lines were imported into Caris HIPS/SIPS software, gridded into a 10-m base surface and imported into a GIS. Nearshore data within California State waters were collected between 2006 and 2009 by California State University, Monterey Bay, Seafloor Map- 
ping Lab, and Fugro Pelagos for various seafloor habitat and geology studies. These data are available as GIS files from http://seafloor.csumb.edu/index.html. USGS nearshore data are available as GIS files from online reports including http://pubs. usgs.gov/of/2007/1271/ and http://pubs.usgs.gov/of/2009/1289/, as well as from active investigations.

The nearshore, higher resolution bathymetry data were down-sampled to $10-\mathrm{m}$ resolution grids to merge with the deeper-water grids. All datasets were transformed to UTM, zone 11, NAD83 coordinates relative to the NAVD88 ellipsoid. Using the ESRI GRID "merge" function, all of the bathymetry data were combined with priority given to the most recent datasets (fig. 5). standard for first-order surveys of $0.5 \mathrm{~m}$ for areas shallower than $100 \mathrm{~m}$, however there are outlier cells that exceed both first- and even second-order standard thresholds.

The majority of the seafloor mapped in 2010 and 2011 consists of low-relief, low-backscatter sedimented seafloor. In the northwest area, there are two east-west-trending ridges with moderate relief (fig. 3) and higher backscatter intensities (fig. 4). The northern ridge is associated with the Red Mountain Fault (Johnson, oral commun., 2012) while the ridge to the south may be associated with the Ventura-Pitas Point Fault System (Johnson, oral commun., 2012), a region between the ridges that has low relief but moderate backscatter intensities compared to the southeast. Without ground-truth information we

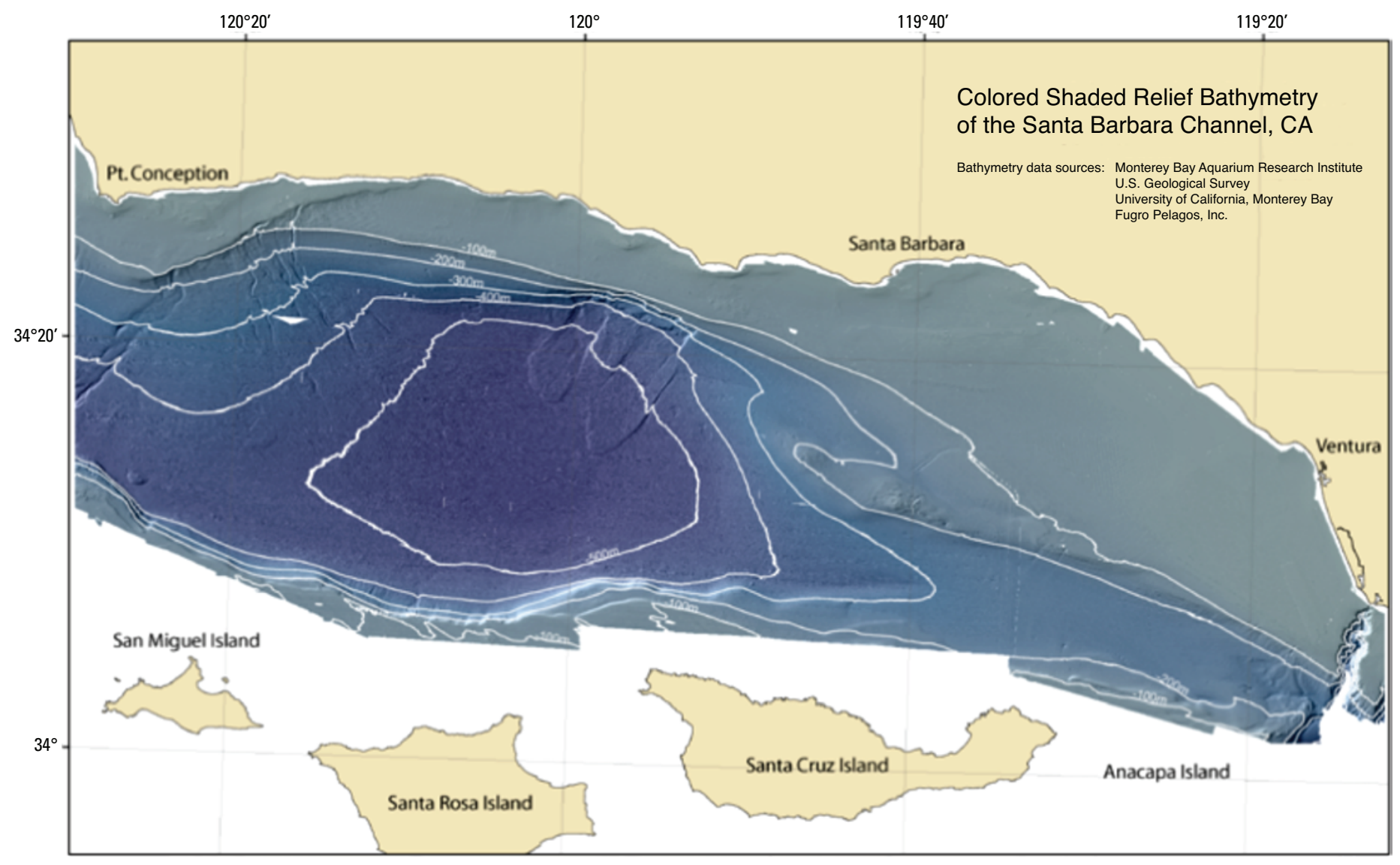

Figure 5. Colored shaded-relief bathymetry map of the Santa Barbara Channel generated by merging available swath bathymetry data including the new 2010-2011 USGS data.

\section{Survey Results}

The 2010 and 2011 USGS surveys of the outer mainland shelf in the eastern Santa Barbara Channel covered about 200 $\mathrm{km}^{2}\left(76 \mathrm{mi}^{2}\right)$. Observed depths ranged from $15 \mathrm{~m}$ to $105 \mathrm{~m}$ (fig. 3). After filtering the data to remove obvious outliers, the standard deviation of the remaining soundings was calculated for each $2 \mathrm{~m}$ x $2 \mathrm{~m}$ cell in Caris HIPS/SIPS software. The mean standard deviation for all cells in the 2010 and 2011 surveys is $0.17 \mathrm{~m}$. There are a few outlier cells with variations as high as $2.09 \mathrm{~m}$. The mean TVU is $0.34 \mathrm{~m}$ and this falls within the IHO presume that this region has either coarser grained sediment or is bedrock covered by a thin layer of sediment. The bathymetry and backscatter data described in this summary, as well as the new overall 10-m resolution Santa Barbara Channel bathymetric DTM, are available for download from the online Data Catalog section of this report (http://pubs.usgs.gov/ds/702/).

NOTE THAT THE USGS COLLECTS BATHYMETRIC DATA FOR SCIENTIFIC PURPOSES ONLY. THE USGS DOES NOT GAURANTEE THAT FULL BOTTOM SEARCH HAS BEEN ACHIEVED AND THE DATA HAVE NOT BEEN INSPECTED FOR DANGERS TO NAVIGATION. 


\section{Acknowledgments}

This work was funded by the Bureau of Ocean Energy Management (BOEM 2012-029) and the U.S. Geological Survey. Thanks to Sam Johnson and Tom Lorenson for reviewing this report. Also thanks to Jamie Grover, Jenny White, and Pete Dal Ferro as captains of the R/V Parke Snavely, to ET's Rob Wyland, Jackson Currie, and Gerry Hatcher for data acquisition, and to Tom Reiss for the RTK base station support. Finally, we thank the Channel Islands National Park for the use of their dock facilities in the Ventura Harbor during a significant portion of the surveys.

\section{References Cited}

Applied Microsystems Ltd., 2005, SVplus sound velocity, temperature, and depth profiler user's manual, revision 1.23: Sidney, B.C., Canada, Applied Microsystems Ltd., 39 p. Carignan, K.S., Taylor, L.A., Eakins, B.W., Warnken, R.R.,
Lim, E., and Medley, P.R., 2009, Digital elevation model of Santa Barbara, California-Procedures, data sources, and analysis: National Ocean and Atmospheric Administration, Technical Memorandum NESDIS NGDC-29, accessed June 2012, at http://www.ngdc.noaa.gov/dem/ squareCellGrid/download/603.

International Hydrographic Organization (IHO), 2008, IHO standards for hydrographic surveys (5th ed.): Monaco, International Hydrographic Bureau Special Publication 44, 28 p.

National Geodetic Survey, 2009, GEOID09 geoid model: National Ocean and Atmospheric Administration, National Geodetic Survey, accessed April 2010, at http://www.ngs. noaa.gov/GEOID/GEOID09/.

Soler, T., and Snay, R.A., 2004, Transforming positions and velocities between the International Terrestrial Reference Frame of 2000 and North American Datum of 1983: Journal of Surveying Engineering, v. 49, p. 49-55.

System Engineering and Assessment (Advanced Products) Ltd., 2004, SWATHplus training pack: Frome, England, System Engineering and Assessment (Advanced Products) Ltd., variously paged.

Table 1. SWATHplus-M Sonar Specification (System Engineering and Assessment (Advanced Products) Ltd., 2004).

\begin{tabular}{ll}
\hline \multicolumn{1}{c}{ Name } & \multicolumn{1}{c}{ Value } \\
\hline Sonar Frequency & $234.5 \mathrm{kHz}$ \\
Maximum Water Depth & $120 \mathrm{~m}$ \\
Maximum Swath Width & $300 \mathrm{~m}$ (typically 7 to 12 times water depth \\
Resolution Across Track (best case) & $5 \mathrm{~cm}$ \\
Transmit Pulse Length & $34 \mathrm{~ms}$ to $500 \mathrm{~ms}$ \\
Ping Repetition Rate & \\
150 -m Swath Width & 10 pings per second \\
300 -m Swath Width & 5 pings per second \\
Vertical Accuracy (Range Dependent) & \\
$57 \mathrm{~m}$ & $0.1 \mathrm{~m}$ \\
$114 \mathrm{~m}$ & $0.2 \mathrm{~m}$ \\
$171 \mathrm{~m}$ & $0.3 \mathrm{~m}$ \\
\hline
\end{tabular}

Table 2. GPS base station coordinates used for the 2010-2011 USGS survey in the eastern Santa Barbara Channel.

\begin{tabular}{ll}
\hline \multicolumn{1}{c}{ Name } & \multicolumn{1}{c}{ Value } \\
\hline Coordinate System: & WGS84 (G1150) \\
Epoch: & $6 / 30 / 2010$ \\
& $(2010.49589041096)$ \\
Latitude: & $\mathrm{N} \mathrm{34} 4^{\circ} 16^{\prime} 34.36316^{\prime \prime}$ \\
Longitude: & $\mathrm{W} 119^{\circ} 17^{\prime} 36.51032^{\prime \prime}$ \\
Ellipsoid Height: & $7.374 \mathrm{~m}$ \\
\hline
\end{tabular}

